\title{
FAST FLUX TEST FACILITY CONTAINMENT SYSTEM ALARM AND TRIP CRITERIA
}

M. M. Hendrickson and V. W. Gustafson

October 1970.

\section{AEC RESEARCH \& DEVELOPMENT ṘEPORT}

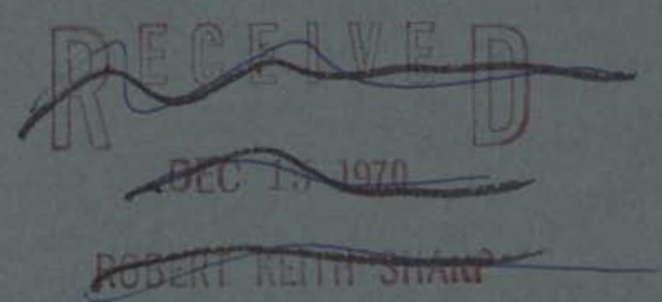




\section{LEGAL NOTICE}

This report was prepored as an account of work sponsored by the United States Government. Neither the United States nor the United States Atomic Energy Commission, nor any of their employees, nor any of thair contractors, subcontractors, or their employees, makes any warranty, express or implied, or assumes any legal liability or responsibiiity for the accuracy, completeness or usefulness of any informofion, apparatus, producf or process disclosed, or represents that its use would not infringe privately owned rights.

\section{PACIFIC NORTHWEST LABORATORY}

RICHLAND, WASHINGTON

operated by

BATTELLE MEMORIAL INSTITUTE

for the

.

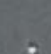

(1)

UNITED STATES ATOMIC ENERGY COMMISSION UNDER CONIRACT AT(45-1)-1830 
BNWL-1479

UC-41, Health

and Safety

\author{
FAST FLUX TEST FACILITY \\ CONTAINMENT SYSTEM ALARM AND TRIP CRITERIA \\ (Atmosphere Radioactivity Measurement Study) \\ M. M. Hendrickson and V. W. Gustafson(a)
}

October 1970

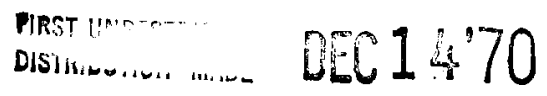

BATTELLE MEMORIAL INSTITUTE

PACIFIC NORTHWEST LABORATORIES

RICHLAND, WASHINGTON 99352

(a) Now employed by WADCO Corp., a Subsidiary of Westinghouse Electric Corp., under AEC Contract No. AT (45-1)-2170 
Printed in the United States of America Available from

Clearinghouse for Federal Scientific and Technical Information National Bureau of Standards, U.S. Department of Commerce Springfield, Virginia 22151

Price: Printed Copy $\$ 3.00 ;$ Microfiche $\$ 0.65$ 
BNWL - 1479

\title{
FAST FLUX TEST FACILITY \\ CONTAINMENT SYSTEM ALARM AND TRIP CRITERIA \\ (Atmosphere Radioactivity Measurement Study)
}

M. M. Hendrickson and V. W. Gustafson

\begin{abstract}
$\underline{\text { ABSTRACT }}$
Potential radioactive releases within the various cells and containment vessel of the Fast Flux Test Facility have been reviewed and a basis has been selected for identifying radioactivity release rates which require containment action. Noble gases were selected as the control isotopes and alarm and ventilation containment trip levels determined on the basis of calculated estimates of the airborne activity at a control point approximately $1 / 4$ mile from the stack assuming all the activity has the characteristics of ${ }^{41} \mathrm{Ar}$. Alarm and containment trip levels are $10^{-4} \mathrm{Ci} / \mathrm{sec}$ emission and $1.0 \mathrm{Ci} / \mathrm{sec}$ emission, respectively. An alarm level was chosen which would result in 1/10 the yearly average permissible concentration at the control point, $1 / 4$ mile from the stack. If activity levels greater than the alarm level, up to the trip level, persisted for the period of up-to 8 hours, a manual ventilation containment trip would be recommended.
\end{abstract}





\section{TABLE OF CONTENTS}

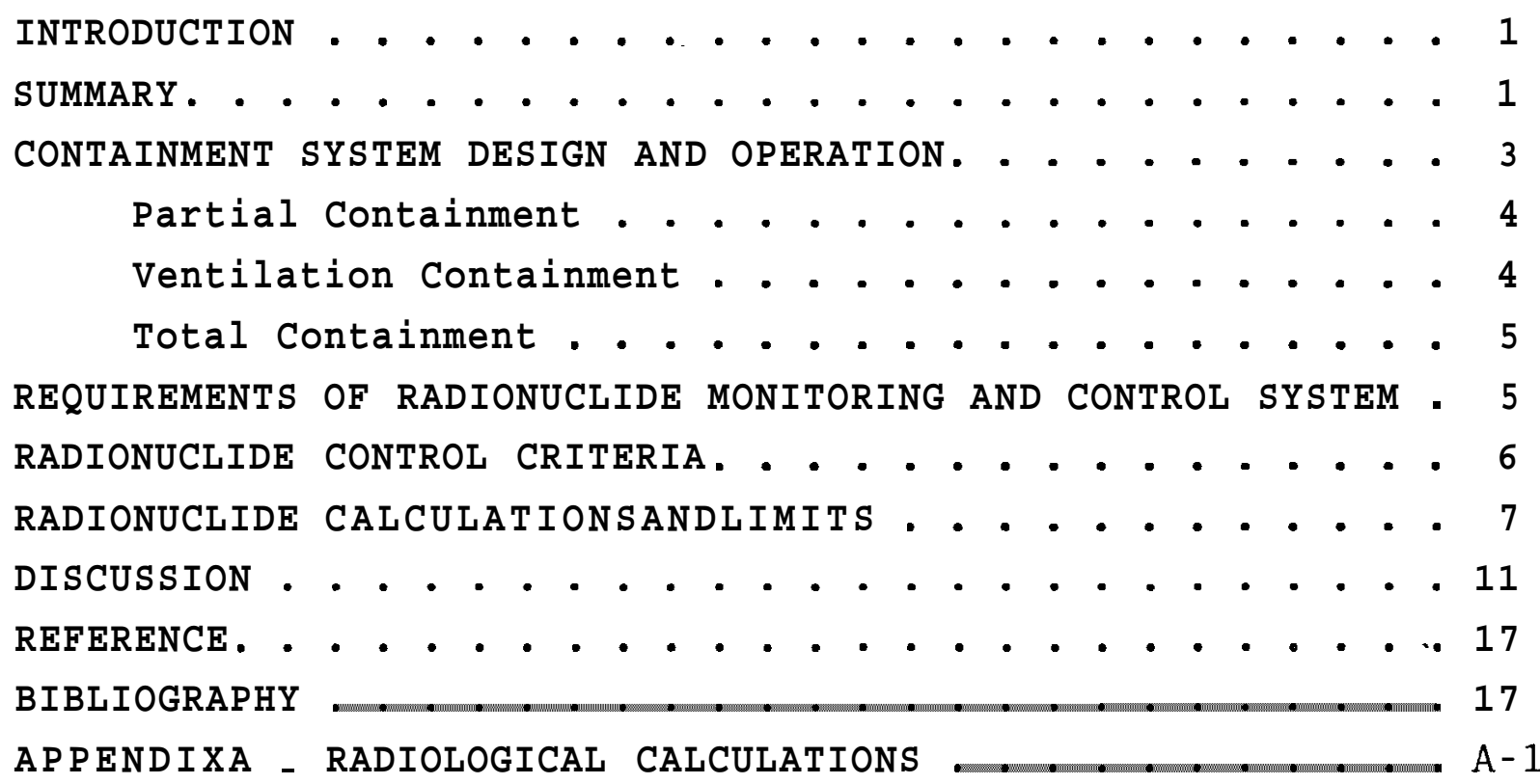



BNWL - 1479

\title{
FAST FLUX TEST FACILITY CONTAINMENT SYSTEM ALARM AND TRIP CRITERIA (Atmosphere Radioactivity Measurement Study)
}

\author{
M. M. Hendrickson and V. W. Gustafson
}

\begin{abstract}
INTRODUCTION
The Fast Flux Test Facility (FFTF) design will provide for controlled exhaust of ventilation air, nitrogen, and inert gases to the atmosphere during normal operations. The passive design features of the containment system in conjunction with the control exercised over ventilation exhaust will prevent release of unacceptable quantities of radionuclides to the environment for both normal operation and off-standard conditions. The purpose of this study is to establish the appropriate criteria and to determine monitoring and control level requirements for actuating the containment system. Radionuclide concentrations in effluent gases from the various equipment cells and the containment vessel will provide the actuating signals for the containment system.
\end{abstract}

\section{SUMMARY}

Potential radioactive releases within the various cells and containment vessel were reviewed and a basis established for estimating the acute radiological consequences. Noble gases were selected as the control isotopes and alarm and containment levels were determined on the basis of calculated estimates of the airborne activity at a control point approximately $1 / 4$ mile from the stack. 
Three modes of containment have been proposed; partial, ventilation and total containment. Partial containment includes isolation of individual equipment cells within the containment vessel when the emission rate of activity exceeds $1.0 \mathrm{Ci} / \mathrm{sec}$. An alarm level is proposed when the activity exceeds $10^{-4} \mathrm{Ci} / \mathrm{sec}$. Ventilation containment consists of closing the containment vessel ventilation supply and exhaust lines when the emission rate of activity exceeds $1.0 \mathrm{Ci} / \mathrm{sec}$. Alarm levels are $10^{-4} \mathrm{Ci} / \mathrm{sec}$. An automatic total containment trip is required when the activity exceeds $1.0 \mathrm{Ci} / \mathrm{sec}$ and the pressure increases in the containment vessel. Total containment requires closure of the ventilation control valves and all other vessel penetrations that could permit venting of any radioactivity to the environs.

Alarm levels and trip points are based on the rate of release of a relatively high energy gamma emitter. Calculations were based on ${ }^{41} \mathrm{Ar}$ which emits a $1.3 \mathrm{MeV}$ y and a $1.2 \mathrm{MeV}$ (max energy) 8 per disintegration. The average $y+\beta$ energy per disintegration is between 1.7 and $1.8 \mathrm{MeV}$, the latter value being used in our calculations. The International Commission on Radiological Protection recommends (1) using $1.8 \mathrm{MeV}$ for ${ }^{41}$ Ar immersion dose calculations. It is not intended that the monitoring system be designed to detect ${ }^{41} \mathrm{Ar}$ specifically, but rather gross gamma in general. Ionization chambers would probably be used for detection and these would be calibrated on the basis of the release rate (and corresponding exposure rate) of ${ }^{41}$ Ar with the assigned energy of $1.8 \mathrm{MeV} / \mathrm{disintegration} \mathrm{(MeV/dis).}$

The proposed limits are based on conservative assumptions and judgements to assure that abnormally high releases of radioactivity are promptly identified and controlled to minimize the amounts released to the environment. These limits 
should be subjected to review and possible change as new information is developed and the design and operating plans become more defined. It is also expected that as operating experience is gained, the limits would be reviewed to determine if some adjustment is appropriate.

It is also emphasized that it is not the purpose of this document to establish limits on radioactivity release for routine operation.

\section{CONTAINMENT SYSTEM DESIGN AND OPERATION}

The FFTF design includes a pressure-tight containment vessel which houses the reactor, the fueling machine, primary coolant system, closed loop cells, and auxiliary spaces. Within the containment vessel, below the main floor, numerous cells or cavities are provided. which contain the various equipment.systems. These cells will be closed during reactor operation and provide the first containment barrier. They will normally be supplied with an inert gas atmosphere.

The operating galleries and containment vessel will be continuously ventilated with fresh air.

The contained atmosphere in individual cells or spaces will be recirculated through roughing filters and conditioning equipment. A 11 air, nitrogen, or inert gases exhausted from the cells or containment spaces will normally be vented to a filter building where it passes through roughing filters, and high efficiency filters before being exhausted to the atmosphere via a 200 foot stack. Exhaust gases from potentially contaminated cells will be diverted to a gas decay holdup system if the activity reaches preset levels.

The FFTF is designed with a double barrier type of containment. Individual equipment cells within the containment 
vessel are designed to contain the initial accident effects from a reactor incident. Design leakage from the cells is less than $10 \%$ per day. The containment vessel will contain the final accident effects and be designed with a leak rate of 1\% per day or less at design pressure.

Three modes of containment operation are proposed; partial, ventilation, and total containment.

\section{PARTIAL CONTAINMENT}

Partial containment includes isolation of individual equipment cells within the containment vessel when radioactivity levels exceed preset limits. Initiation of partial containment will consist of closing the intake and exhaust gas lines to the cell.

Initial containment of aerosols from an accident within the equipment cells will lengthen the time it takes to build up the radionuclide concentration in the containment vessel, thus reducing the average radionuclide concentration of aerosols which would be exhausted or leaked from the containment vessel to the environs. The delay time.permits some decay of radionuclides before leakage occurs to the containment vessel and also permits some plateout or deposition of airborne nuclides. Under normal operating conditions, minor radioactivity releases which occur within individual cells would be contained in the cell. More serious releases would cause isolation of the cell by feed and bleed gas line closure. This would diminish activity release to the containment vessel which otherwise could be sufficiently high to initiate further containment action and reactor shutdown.

\section{VENTILATION CONTAINMENT}

Ventilation containment consists of closing the containment vessel ventilation supply and exhaust lines when the 
BNWL -1479

exhaust air activity exceeds the preset limits. This action will confine the contaminants within the containment vessel.

\section{TOTAL CONTAINMENT}

Since reactor accidents probably would result in increased pressure, the containment vessel. will be designed as a pressure-tight vessel and any penetration that could conceivably permit venting of the contained vapors to the environment will be closed upon indication of a pressure buildup within the vessel. This action will be termed total containment and be initiated upon indication of simultaneous high radioactivity levels (ventilation containment) and pressure.

\section{REQUIREMENTS OF RADIONUCLIDE MONITORING AND CONTROL SYSTEM}

Criterion 70 of the proposed Appendix A of 10 CFR 50 requires as a minimum that "the design for radioactivity control be justified (a) on the basis of 10 CFR 20 requirements for normal operations and for any transient situation that might reasonably be anticipated to occur and (b) on the basis of $10 \mathrm{CFR} 100$ dosage level guidelines for potential reactor accidents of exceedingly low probability of occurrence". This criterion is applicable to FFTF and is supplemented at Hanford by the requirements of AECM-0524 and RL Appendix 0510.

The design for radioactivity control in the FFTF will include the passive features of the plant structure, a pressure-tight vessel and individual cells within, and the plant protection system designed to control radionuclide release via the ventilation system and other potential leakage paths to the environment.

Suitable alarm and containment actuating features will be provided to assure that radionuclide releases by the normal ventilation exhaust system do not exceed preset limits. Two 
radionuclide concentration control levels are proposed. The first level is an alarm level to indicate increasing radioactivity concentrations, permitting corrective action before radioactivity reaches a level that would require curtailment of operations. The alarm level should be low enough to permit a reasonable time for correction before a manual actuation of partial or ventilation containment is required. The second control level will be the containment trip or actuation level. This level should be established so that no alternative action exists except to automatically initiate containment to prevent a release of radionuclides, via the ventilation system and the passive containment features, that would result in exceeding the dosage level guidelines of 10 CFR 100.

Continuous monitoring of the containment vessel exhaust gases will be required to meet the ventilation containment actuation and alarm requirements. In addition, suitable recording instrumentation will be required to quantitatively measure acute release to the environment. Measurement information will include the date of record and the amount of radioactivity released.

Continuous monitoring of the bleed gases from individual cells will be required to initiate partial containment of these areas. Area monitoring is required in these cells since the cells are normally closed except for gas flow during periods of makeup for inert gas purity control.

\section{RADIONUCLIDE CONTROL CRITERIA}

Chronic releases of radioactive material during normal operations must be within the concentration guides of Table 2 of AECM-0524 Arnex A. This Annex describes concentrations which are to be met at the point of uncontrolled release to the environs. In this study the point of uncontrolled release is 
considered to be a distance of $1 / 4$ mile from the stack. This distance represents the point of maximum radionuclide concentration with conservative atmospheric assumptions. A literal interpretation of AECM-0524 permits calculation of compliance with concentration guides at the plant boundary, about 4-1/2 miles; however, the impact of waste released by all Hanford contractors should be controlled so that exposures to off plant population groups will be within the guides. Further, the effect of waste released beyond the immediate area of the facility should be controlled so that radiological exposures to other Hanford contractor facilities and personnel will be minimized consistent with the limits for off-plant population groups. In addition, selection of the shorter distance for the control point will allow for future utilization of land on the Hanford site and prevent any future restrictions on reactor operations that could result from the ulitization there of.

\section{RADIONUCLIDE CALCULATIONS AND LIMITS}

Emission rates for alarm and trip levels were calculated on the basis of permissible concentrations of ${ }^{41}$ Ar. Argon-41 was selected for the calculations because it is a reasonably representative high energy beta and gamma emitter and because it is always expected to be present and released to some degree as a result of its use as a cover gas in the FFTF. For postulated accidents where ${ }^{41}$ Ar may not be a significant contribution to the total release, other similar gammaemitting noble gases would be present.

AECM-0524 lists the maximum permissible yearly average concentration (immersion in a semi-infinite cloud) of ${ }^{41} \mathrm{Ar}$ as 
$4 \times 10^{-8} \mu \mathrm{Ci} / \mathrm{ml}$. Assuming this value as the control level at $1 / 4$ mile, the emission rate is calculated to be approximately $10^{-3} \mathrm{Ci} / \mathrm{sec}$. Appendix A describes the calculational model and the assumptions used to arrive at this number. Figure 1 shows the airborne specific activity of ${ }^{41}$ Ar which would give an emission rate of $10^{-3} \mathrm{Ci} / \mathrm{sec}$ for various volumetric discharge rates from the building.

Alarm and containment trip levels were selected on the basis of controlling the annual emission within the exposure guides of AECM-0524 and of controlling the total emission in a potentially severe accident to dose values well within the guidelines of $10 \mathrm{CFR} 100$. An alarm level of $10^{-4} \mathrm{Ci} / \mathrm{sec}$ is proposed which is $1 / 10$ of the annual average emission rate of $10^{-3} \mathrm{Ci} / \mathrm{sec}$ as calculated above for ${ }^{41} \mathrm{Ar}$. Realizing that ${ }^{41} \mathrm{Ar}$ or a mixture of fission product noble gases would be present in the reactor cover gas and would likely be the radioactivity most commonly observed in off gases, a fraction of the permissible concentration of ${ }^{41}$ Ar was selected. This level should in no way restrict the operation of the facility but would provide a level sufficiently low to permit early detection of potential cover gas problems so as to minimize radionuclide release to the environs.

The ventilation containment trip level proposed is a factor of $10^{4}$ above the alarm level or $10^{3}$ times the maximum permissible yearly average concentration. Emission at this rate, $1 \mathrm{Ci} / \mathrm{sec}$, for an 8 hour shift would result in a whole body dose at $1 / 4$ mile of less than 0.5 rem, the dose which would result from a year long exposure to AECM-0524 concentrations of noble gases. The dose was calculated assuming a semiinfinite cloud and no wind speed or direction variation during the entire 8 hours. The unmodified calculated value was 0.7 rem at the control point, 1/4 mile. This unmodified value 


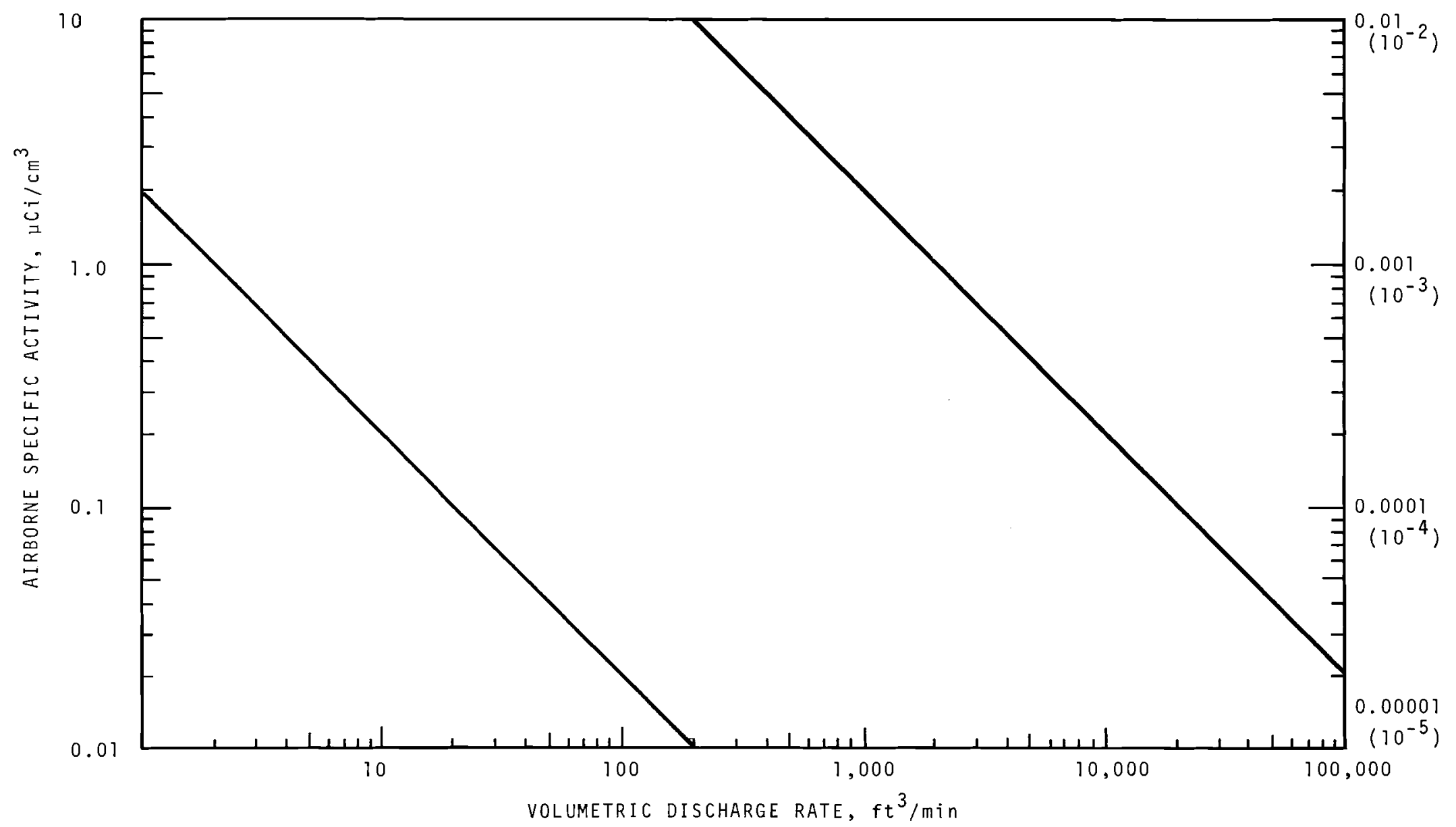

FIGURE 1. Airborne Specific Activity and Volumetric Discharge Rate Which Corresponds to an Emission Rate of $10^{-3} \mathrm{Ci} / \mathrm{sec}$ 
BNWL -1479

would be expected to be reduced by a factor of from 4 to 10 because of variations in wind speed and direction over the 8 hour period. An additional reduction in the estimate in the dose would result from taking into account the finite dimensions of the cloud.

The proposed trip limit is also low enough that standard ventilation valves and actuating mechanisms can be used to stop the flow of exhaust gases before any significant release to the environs would occur as a result of a serious reactor accident. Calculations were made to determine the expected maximum dose at the control point of $1 / 4$ mile radius if a ventilation closure time of 10 seconds was assumed. Using the fission product release fractions of Table 1 and taking into account the low leak rates from the individual cells, the expected dose at the control point, $1 / 4$ mile, would be 1 ess than 0.01 rem.

TABLE 1. Estimated Airborne Activity

Total

Inventory

i n Core,

Nuclide Group

Noble Gases

Halogens

Volatile Solids

( $\mathrm{Se}, \mathrm{Te}, \mathrm{Cs})$

All Other Fission Products

TOTAL
Fraction

Assumed

Airborne

100

20

10

0.12

1.2

$\underline{8.4}$

10

$\underline{0.84}$
Airborne Activity, $\times 108$ 
The proposed alarm and trip levels are applicable to individual cells and the containment vessel and related spaces. Table 2 summarizes the alarm and containment trip levels for the various containment spaces. An alarm level indication in exhaust gases from individual cells should also initiate diversion of the gases from the normal ventilation exhaust system to the Radioactive Gas Decay and Disposal System. This will minimize activity released to the environs by permitting some decay time before disposal via the central filter facility and stack.

The emission rates proposed for limits are easily converted to concentration levels for different areas by dividing the emission rate by the volumetric flow rates of the individual cells or process area.

\section{DISCUSSION}

Actual composition of an aerosol released to the environs in a reactor accident is not easily predicted. The composition of the aerosol and gases depends on many factors including prior irradiation history of the fuel, cooling time of fuel, aerosol behavior, and filter effectiveness.

If the aerosol contained radionuclides other than the noble gases, these nuclides would be subject to some degree of filtration. The high efficiency particulate filters in the central filter building would be expected to remove at least $99.0 \%$ of particulates 0.3 micron size or greater.

In addition, in-cell particulate filters will have a design efficiency of $99.0 \%$ for particulates, the same as in the central filter building. The effect of the filters is to greatly reduce the amount of particulate and halogen activity released in relation to that of noble gases. Thus, the total activity released to the environs would be less than that 
TABLE 2. Summary of Alarm and Containment Trip Actions and Levels

Partial Ventilation Containment (Applies to inerted containment spaces)

Exhaust Activity Release Rate, $\mathrm{Ci} / \mathrm{sec}$

Alarm--Alert that abnormal condition exists which requires corrective action

$10^{-4}$
$10^{-4}$
(persisting for 1 shift)

Divert bleed gases to the Decay and Disposal System

Trip---Automatically divert exhaust gases to Decay and Disposal System and stop feed and bleed from area of high activity

Ventilation Containment

(Applies to containment vessel)

Alarm--Alert that abnormal condition exists which requires corrective action $10^{-4}$

Trip---Manual slow shutdown, close ventilation containment $10^{-1}$ valves of containment vessel (persisting for 1 shift)

Trip---Automatically close ventilation control valves of containment vessel

Total Containment

(Applies to containment vessel)

Trip---Close all possible penetrations of containment vessel, Abnormally high pressure in conjunction with the scrams reactor release indicated for automatic ventilation containment trip 
estimated by assuming that a 11 the measured activity upstream of the filters was noble gases. The average gamma decay energy of the mixture would be 1 ess than $1.8 \mathrm{MeV}$, the value used in the calculations and the decay energy value which is suggested for ${ }^{41} \mathrm{Ar}$ immersion dose calculations by the International Commission on Radiological Protection. (1) The combined assumptions on total activity released and average decay energy result in a conservative estimate of the activity released.

Potentially serious releases of radioactive material involve the melting of fuel or the burning of large quantities of sodium. In either case, large amounts of gamma emitters will be present. In addition, accidents which are potentially serious with regard to consequences in the environs will have noble gases present in large quantities. The noble gases are most readily released, are present in all recently irradiated fuel, and are readily detected by gamma monitoring. In a sodium cooled reactor, long-lived nonvolatiles have a relatively low potential for release compared to noble gases. In addition, fuel cooled for a long time ( 5 xenon 133 halflives, about 30 days) is not subject to the same release potential as recently irradiated fuel. Thus, in any radiologically significant accident, a substantial fraction of the released activity will be gamma emitting noble gases or radioactive sodium. For containment trip purposes, it is therefore not considered necessary to monitor selectively for individual fission products.

If operating experience establishes that the radionuclide composition of leaked gases from a region is significantly different from a radiological standpoint, this information may be used to establish allowable trip points instead of the limits based on ${ }^{41}$ Ar. 
The meteorological conditions chosen for the calculations did not include long-term dilution effects such as shifts in wind direction, added dilution with increased wind speeds, and changes in atmospheric stability. A more detailed accounting of these long-term effects would permit alarm levels to be set higher than proposed by this study. If dispersion tests, meteorological records, or environmental sampling can establish greater dispersion or atmospheric dilution factors, these data may be used for modifying the alarm and trip levels. As an example, wind rose data could be used to establish the dilution factor applicable for the chronic release case instead of the factor used in this'study which is very conservative.

The containment alarm levels have been established on the basis of safe emission from the facility to a control point outside in the environs. It is worth noting that the alarm levels are not meant to be related to radiation protection of personnel within the containment vessel. Using the design values for the containment vessel volume and ventilation flow rate, the radionuclide concentration within the vessel was calculated that would be sufficient to initiate a containment alarm. The calculated concentration was $4 \times 10^{-5} \mu \mathrm{Ci} / \mathrm{cm}^{3}$. This is approximately 100 times the maximum permissible concentration for breathing air limits in uncontrolled areas and requires that suitable radiation protection instrumentation be provided within the vessel to protect working personnel from these kinds of radiation levels.

Consideration was given to monitoring specifically for radioactive isotopes of sodium, iodine, cesium, strontium, tritium, and plutonium. It was concluded that it is impractical and unnecessary to install equipment for trip or alarm purposes which monitors specifically for these isotopes. Measuring the gross activity provides sufficient information for alarm and trip purposes to conclude that action is warranted. 
For long-term control, it is necessary to record the amount of noble gases, iodine, and particulates which are being released; noble gases because they comprise most of the released activity but cause little environmental contamination, iodine because it has the potential for entering the food chain in surrounding areas, and particulates because they would have the major potential for any long-term environmental contamination.

Consideration has also been given to the possible occurrence of accidents which might result in significant airborne plutonium activity without fission product activity. The potential for the release of large amounts of plutonium would result either from a reactot excursion or loss of coolant capacity to irradiated fuel. In a core nuclear excursion, sufficient fission products would be formed even with green fuel to indicate if radionuclides including plutonium were airborne. Plutonium would not become airborne selectively. Noble gases present would be released if fuel melted and the major fraction of the airborne activity would be caused by them.

Most of the activity routinely released from FFTF is expected to be noble gases, primarily ${ }^{41}$ Ar from cover gas activation or xenon and krypton from fuel pins. If vented fuel elements are used there would be additional release of ${ }^{85} \mathrm{Kr},{ }^{133} \mathrm{Xe}$ and ${ }^{135} \mathrm{Xe}$. KL Appendix 0510 does nor give guidance for release of these radionuclides; therefore, AECM-0524 li mits should be followed for these and other noble gases, and tritium and ${ }^{14} \mathrm{C}$.

The required response times of monitoring and actuating equipment will be dependent on several things. Generally, the response times are not important for- detection of alarm levels but are important for trip levels. At the trrp levels proposed, calculations indicated that actuation and closure time 
in 10 seconds was completely adequate for any conceivable accident conditions and could be longer based on compliance with 10 CFR 100 guidelines. However, since it is desirable to minimize any release of radionuclides to the environment, it is recommended that a response time on the order of 10 seconds or less be specified. This time limit is based upon radionuclide detection at the point of closure. If the ventilation rates were reduced from those in Appendix A or if the detection location is upstream of the closure, the response times could be increased. In general, time responses for containment actuation on a radiological basis could be longer than is specified for most reactors; however, in most instances, shorter times are specified so as to prevent blowout of filters in a pressurization accident. This latter point may be a consideration in designing the control system for the individual cells but probably will not be a consideration for the main ventilation system since pressure increases for the FFTF containment vessel are relatively slow in comparison with those in water reactors where rapid pressure increases result from the steam formed in the coolant blowdown. 
BNWL - 1479

\section{REFERENCE}

1. Report of Committee 11 on Permissible Dose for Internal Radiation ICRP Publication 2, Pergamon Press, Long Island, New York, 1959.

\section{B I B L IOGRAPHY}

1. AEC Manual, Chapter 0524 and RL Appendix 0510.

2. Bechtel Drawings of FFTF Reactor Containment Building and Service Buizding SK-10150 to SK-10170.

3. Code of Federal Regulation, Title 10, Part 20.

4. Code of Federal Regulation, Title 10, Part 100.

5. C. J. Foley. PFTF Conceptual Design Description for the Inert Gas Receiving and Processing System - No. 82, BNWL-500, vol. 82. Battelle-Northwest, Richland, Washington, December, 1968.

6. M. M. Hendrickson. EXDOSE - A Computer Program for CaZculating the External Gamma Dose from Airborne Fission Products BNWL-811. Battelle-Northwest, Richland, Washington, $\overline{\text { September }}, 1968$.

7. B. Shaver. FFTF Conceptual Design Description for the Heating and Ventilating System No. 25 BNWL-500, vol. 25. Battelle-Northwest, Richland, Washington, December, 1969.

8. C. C. Steel. FFTF Conceptual Design Description for the Containment System No. 27 BNWL-500, vol. 27. BattelleNorthwest, Richland, Washington, February, 1969.

9. Supplementary Criteria and Requirements for RDT Reactor Plant Protection Systems, Proposed RDT Standard C-16-1, Revision E-1. 

BNWL - 1479

APPENDIX A

RADIOLOGICAL CALCULATIONS 
BNWL -1479

APPENDIX A

RADIOLOGICAL CALCULATIONS

Alarm levels and trip points are based on the release rate of a $1.8 \mathrm{MeV} / \mathrm{dis}$ gamma emitter. Argon-41 (which is assigned a decay energy of $1.8 \mathrm{MeV} / \mathrm{dis}$ in ICRP recommendations) was selected as a nuclide whose properties would be adequately representative for purposes of determining alarm levels and containment trip levels.

Downwind time integrated airborne concentrations of nuclides (hereafter abbreviated to "concentration") and doses were calculated which would result from emission of activity from the containment system. The exposure point was assumed to be $1 / 4$ mile (400 meters) from the stack. The atmospheric dilution was calculated based on a point source emission at 200 feet in unstable atmospheric conditions when the average wind speed was $1 \mathrm{~m} / \mathrm{sec}$. Sutton's equation with appropriate parameter values was used. The selection of these conditions was based on comparison of peak concentrations for a variety of conditions (unstable, neutral, and stable). The condition giving the maximum concentration at the closest distance, for a 200 foot release was selected. This distance is $1 / 4 \mathrm{mile.}$ The dilution factor (normalized time integrated airborne concentration, E/q) chosen was $5 \times 10^{-5}$. This value is repre-. sentative of concentrations which might be expected for a short duration release and unstable conditions but is conservative for long duration releases. Long duration releases of 8 hours to 1 day show more dilution by a factor estimated to be 4 to 10 .

For chronic releases more detailed accounting of stability conditions, wind speed and especially wind direction would 
show much more dilution (lower time integrated airborne concentration) at any downwind point.

The dilution factor (normalized concentration) of $5 \times 10^{-5} \mu \mathrm{Ci} \cdot \mathrm{sec} / \mathrm{cm}^{3} \cdot \mathrm{Ci}$, is a conservative choice for three reasons; (1) it was calculated at a distance well within the plant boundaries, (2) it is the highest peak concentration, and (3) it was calculated for a short duration release.

MATHEMATICAL FORMULA USED

The emission rate from the containment vessel is:

$$
\begin{aligned}
\frac{\mathrm{d} Q}{\mathrm{~d} t} & =\mathrm{LQ} \text { Ci/sec } \\
Q & =\text { airborne activity in container (curies) } \\
L & =\frac{\text { leakage rate from container (cfs) }}{\text { volume of container }\left(\mathrm{ft}^{3}\right)}\left(\mathrm{sec}^{-1}\right)
\end{aligned}
$$

$\frac{d Q}{d t}$ must by definition result in concentrations less than MPC (as shown in AECM-0524 Table 2) at 400 meters.

$$
\begin{aligned}
\mathrm{C}_{\mathrm{a}}= & \text { downwind concentration } \\
\mathrm{E} / \mathrm{Q}= & \frac{\text { normalized time integrated air concentration }}{\mathrm{cm}^{3} \cdot \mathrm{Ci} \text { released }} \\
\mathrm{MPC}= & 4 \times 10^{-8} \frac{\mu \mathrm{Ci}}{\mathrm{cm}^{3}} \text { for }{ }^{41} \mathrm{Ar}
\end{aligned}
$$

neglecting decay over the short downwind distance and assuming $\mathrm{C}_{\mathrm{a}}$ and $\mathrm{L}$ are constant (both are conservative assumptions)

$$
\begin{aligned}
& \Delta Q=L Q \Delta t=\text { curies released } \\
& \Delta t=\text { time of emission and of exposure (seconds). }
\end{aligned}
$$


The average downwind concentration is $\mathrm{C}_{\mathrm{a}}\left(\mu \mathrm{Ci} / \mathrm{cm}^{3}\right)$ and is to be equal to the MPC.

$$
C_{a}=\frac{E}{Q} \frac{\Delta Q}{\Delta t}=\operatorname{MPC} \frac{\mu C i}{\mathrm{~cm}^{3}}
$$

So

$$
\frac{\Delta Q}{\Delta t}-\frac{\mathrm{MPC}}{\mathrm{E} / \mathrm{Q}}-\frac{4 \times 10^{-8}}{5 \times 10^{-}}=8 \times 10^{-4} \simeq 10^{-3} \frac{\mathrm{C} \mathrm{i}}{\mathrm{sec}} .
$$

From this the desired fraction or multiple of the emission rate for an alarm or trip setting can be calculated corresponding to an MC determined for a downwind point.

ESTIMATE OF WHOLE BODY DOSE FOR A RELEASE OF ${ }^{41} \mathrm{Ar}$

The external whole body dose over a time At for a semiinfinite uniform cloud of constant activity during At is:

$$
\mathrm{D}=0.26 \mathrm{C}_{\mathrm{a}} \mathrm{E}_{\gamma^{\mathrm{At}}} \quad \mathrm{rads}
$$

Ey = average gamma energy per disintegration MeV.

Substituting $C_{a}=\frac{E}{Q} \frac{\Delta Q}{\Delta t}$

$$
D \simeq 0.26\left(\frac{E}{Q}\right)\left(E_{\gamma}\right)(\Delta Q) \quad \mathrm{rads} .
$$

The released quantity, $\Delta Q$, for a given dose at $1 / 4$ mile for $\mathrm{E}_{\mathbf{Y}}=1.8 \mathrm{MeV},{ }^{41}$ Argon, ${ }^{(1)}$ and $\mathrm{E} / \mathrm{q}=5 \times 10^{-5}$ is:

1. For 25 rem $\Delta Q=1.1 \times 10^{6} \mathrm{Ci}$.

2. For 0.5 rem $\Delta Q=2.1 \times 10^{4} \mathrm{Ci}$.

3. For 0.1 rem $A Q=4 \times 10^{3} \mathrm{Ci}$.

4. For $0.01 \mathrm{rem} \Delta \mathrm{Q}=4 \times 10^{2} \mathrm{Ci}$.

Averaee Gamma Enerey For Noble Gases

Figure A-1 shows the average gamma decay energy per disintegration for a typical mixture of noble gases as a function of time after shutdown. The curves take into account the relative 


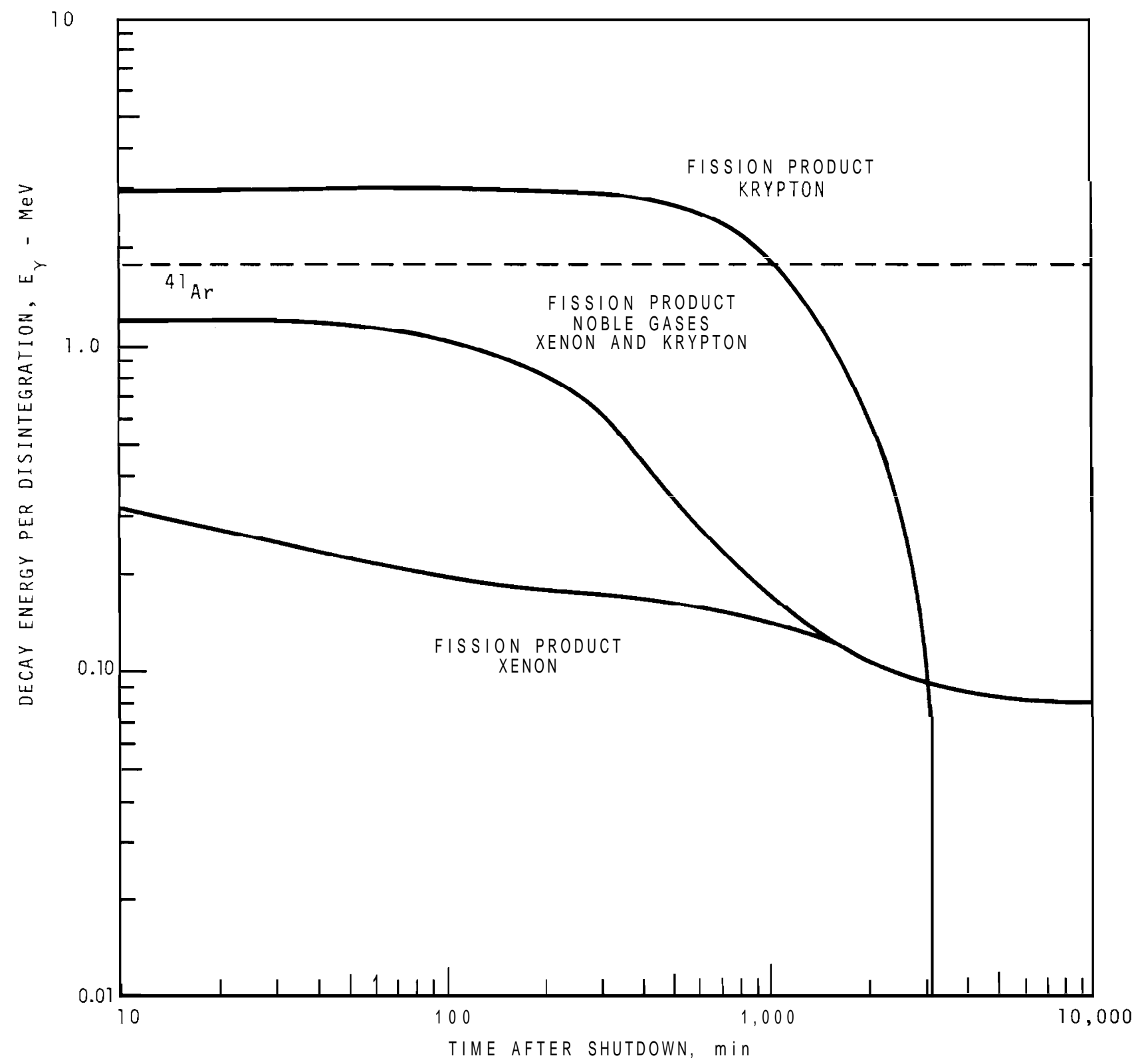

FIGURE A-1. Average Gamma Energy Disintegration Fission Product Noble Gases as a Function of Time After Shutdown, Typical Fuel 
abundance of the isotopes in the fuel. It is reasonable to assume that this relative abundance is maintained when fuel melts and the noble gases are released. The average energy for Krypton is very high in this plot because of inclusion of the ${ }^{88} \mathrm{Rb}$ daughter decay energy.

The average energy of a fission product mixture of noble gases does not exceed 1.2 $\mathrm{MeV}$ and decreases to $1.0 \mathrm{MeV} 2$ hours after shutdown. In all cases it is below the value assumed for ${ }^{41} \mathrm{Ar}, 1.8 \mathrm{MeV}$. (1)

The use of ${ }^{41} \mathrm{Ar}$ as representative of the noble gases is therefore a conservative approach to the problem. 



\section{$\underline{\text { DISTRIBUTION }}$}

No. of

$\underline{\text { Copies }}$

\section{OFFSITE}

AEC Chicago Patent Group

G. H. Lee

26 AEC.Division of Reactor Development and Technology

Director, RDT

Asst D i r for Nuclear Safety

Analysis \& Evaluation Br, RDT:NS

Asst D ir for Plant Engrg, RDT

Facilities Br, RDT:PE

Components $\mathrm{Br}, \mathrm{RDT}: \mathrm{PE}$

Instrumentation \& Control Br, RDT:PE

Liquid Metal Systems Br, RDT:PE

Asst D i r for Program Analysis, RDT

Asst D ir for Project Mgmt, RDT

Liquid Metals Projects Br, RDT:PM

G. J. Mishko

FFTF Project Manager, RDT:RE

Asst D i r for Reactor Engrg, RDT

Control Mechanisms B r, RDT:RE

Core Design Br, RDT:RE (2)

Fuel Engineering $B r, R D T: R E$

Fuel Handling $B \mathrm{r}$, RDT:RE

Reactor Vessels Br, RDT:RE

Coolant Chemistry Br, RDT :RT

Fuel Recycle Br, RDT:RT

Fuels \& Materials Br, RDT:RT

Reactor Physics Br, RDT:RE

Special Technology Br, RDT:RT

Asst D ir for Engrg Standards, RDT

LMFBR Program Manager, RDT :PM

267 AEC Division of Technical Information Extension

1 AEC Idaho Operations Office

Nuclear Technology Division

C. W. Bills, Director

1 AEC San Francisco Operations Office Director, Reactor Division 
No. of

Copies

5

$\underline{\text { AEC Site Representatives }}$

Argonne National Laboratory - CH

Argonne National Laboratory - ID

Atomics International

General Electric Company

Westinghouse Electric Corporation

4 Argonne National Laboratory

R. A. Jaross

G. Krishnan

LMFBR Program Office

N. J . Swanson

1 Atomic Power Development Assoc.

Document Librarian

$5 \quad$ Atomics International

FFTF Program Office

2 Babcock \& Wilcox Co.

Atomic Energy Division

S. H. Esleeck

G. B. Garton

1 Bechtel Corporation

J . J . Teachnor

1 Combustion Engineering 1000 MWe Follow-On Study

W. P. Staker, Project Manager

1 Combustion Engineering

911 West Main Street

Chattanooga, Tennessee 37401

Mrs. Ne11 Holder, Librarian

$4 \quad$ General Electric Company

Advanced Products Operation

Karl Cohen

1 General Electric Company

Nucleonics Laboratory

Dr. H. W. Alter 
No. of

Copies

2 Gulf General Atomic Inc.

General Atomic Division

D. Coburn

1 Idaho Nuclear Corporation

J . A. Buckham

1 Liquid Metal Engineering Center

R. W. Dickinson

2 Liauid Metal Information Center

A. E. Miller

3 Oak Ridee National Laboratory

W. 0. Harms

$1 \quad$ Stanford University

Nuclear Division

Division of Mechanical Engrg

R. Sher

1 United Nuclear Corporation

Research and Engineering Center

R. F. DeAnge 1 is

10 Westinghouse Electric Corporation

Atomic Power Division

Advanced Reactor Systems

D. C. Spencer

ONSITE - HANFORD

1 AEC Chicago Patent Group

R. K. Sharp

2 AEC Rich1and Operations Office

J. M. Shivley

1 Bechtel Corporation

W. A. Smith (Richland) 
No. of

Copies

2

RDT Assistant Director for

$\underline{\text { Pacific Northwest Laboratories }}$

67

WADCO Corporation

J. K. Anderson

A. L. Bement Sr.

J . J . Cadwe 11

C. J. Foley

V. W. Gustafson

J. W. Hagan

J. P. Hale

R. B. Hall

H. E. Hanthorn

R. E. Heineman

K. M. Horst

R. G. Ibatuan

R. L. Junkins

J . E. Mills

J. W. Mitchell

R. E. Peterson

M. O. Rankin

J . C. Richardson

F. H. Shade 1

B. O. Shaver

D. E. Simpson

C. C. Steele

D. D. Stepnewski

G. H. Strong

R. C. Walker

J. H. Westsik

M. F. Wiitala

WADCO Document Control (15)

WADCO Technical Publications

M. M. Hendrickson (25)

C. Unruh

E. C. Watson

N. G. Wittenbrock

Technical Information (5)

Technical Publications (2) 